\title{
Evaluation of Response Reduction Factor of Existing Masonry Infilled RC-Buildings in Pokhara
}

\author{
Tekkan Pandit ${ }^{1}$, Hemchandra Chaulagain ${ }^{2}$ \\ ${ }^{1}$ Post Graduate Student, MSc. in Structural Engineering, School of Engineering, Pokhara University, Pokhara, Nepal. \\ ${ }^{2}$ Assistant Professor, School of Engineering, Pokhara University, Pokhara, Nepal \\ E-mail: hchaulagain@pu.edu.np
}

Received on: $26^{\text {th }}$ May., 2020

Accepted for publication: $30^{\text {th }}$ Oct., 2020

\begin{abstract}
Most of the structural designer do not consider masonry infill walls during design process due to a lack of modeling guidelines in design standards and are treated as non-structural elements. In fact, the interaction effect between bounding frames and infill masonry is a complicated issue in nonlinearity of structures. The current seismic codes indirectly incorporate the nonlinear response of structure through linear elastic approach by considering the response reduction factor ' $R$ ' without comprising infill. In this context, this study evaluates the response reduction factor of existing engineered designed RC frame structures that are designed based on Indian standard codes. For this, three existing RC buildings were selected and performed non-linear pushover analysis. The structural response was examined in terms of natural period, base shear, strength, stiffness, ductility and response reduction factor. The results specify that the buildings with infill walls significantly influence on ' $R$ ' value of structures. Additionally, study shows that the variation of ' $R$ ' value mainly depends on the percentage of infill inclusion.
\end{abstract}

Keywords: Infill wall, Response reduction factor, RC building, Ductility factor, Overstrength, Nonlinear analysis.

\section{Introduction:}

In the past, Nepal has experienced 7 catastrophic earthquakes in different epicentral locations of the country. More recently, the massive Gorkha earthquake of magnitude $7.7(\mathrm{Mw})$ occurred on 25 April 2015 caused around 9000 casualties, 20,000 injuries, and more than 500,000 houses were destroyed (USGS 2018; Bilham 2015). In fact, Nepal is located in the highly seismically active region. The global seismic hazard map highlighted Nepal in a high seismic zone (zone V) with possible shaking of MMI IX or above with a $10 \%$ probability of exceedance in 50 years [1].
Similarly, as presented in Fig. 1, the seismic hazard map of Nepal shows the peak horizontal acceleration at bed rock for Pokhara is up to 400 gals [2]. The peak ground acceleration at rock and soil sites in western Nepal were found 0.29 and $0.39 \mathrm{~g}$, respectively, at $10 \%$ probability of exceedance in 50 years [3].

Reinforced concrete (RC) building with masonry infills is the most common construction practice all around the world. Often, engineers do not consider masonry infill walls in the design process due to a lack of modeling guidelines in design codes and are treated as non-structural elements. 
In fact, the interaction effect between bounding frames and infill walls is a complicated issue when nonlinearity response occurs. It is appropriate if the frame and infill panels are taken separately by considering enough gap in-between [4]. Yet, this approach is rarely used in common practice due to difficulties in maintaining uniform gap between the wall and frame. In fact, masonry infill can drastically modify the structural response and make the structure more vulnerable if the influence of infill is not properly considered during design and construction [5]. However, the contribution of infill to the building response can be positive or negative, depending upon its configuration, position, strength and stiffness of the frames and infills [6]. As indicated in Fig. 2, introduction of the masonry infill in RC frame changes the lateral load-transfer mechanisms of the structure from predominant frame action to the predominant truss-action causing reduction in bending moments and increase in axial forces in the frame member [7]. During earthquake, the large in-plane stiffness and strength of the infills wall lead to a substantial increase in the robustness of building which could be regarded globally as the advantage of these walls. On the other hand, the induced local phenomena such as short-column effect, soft-story effect, torsion, and out-of-plane collapse could be the disadvantage of these walls (see Fig. 3).

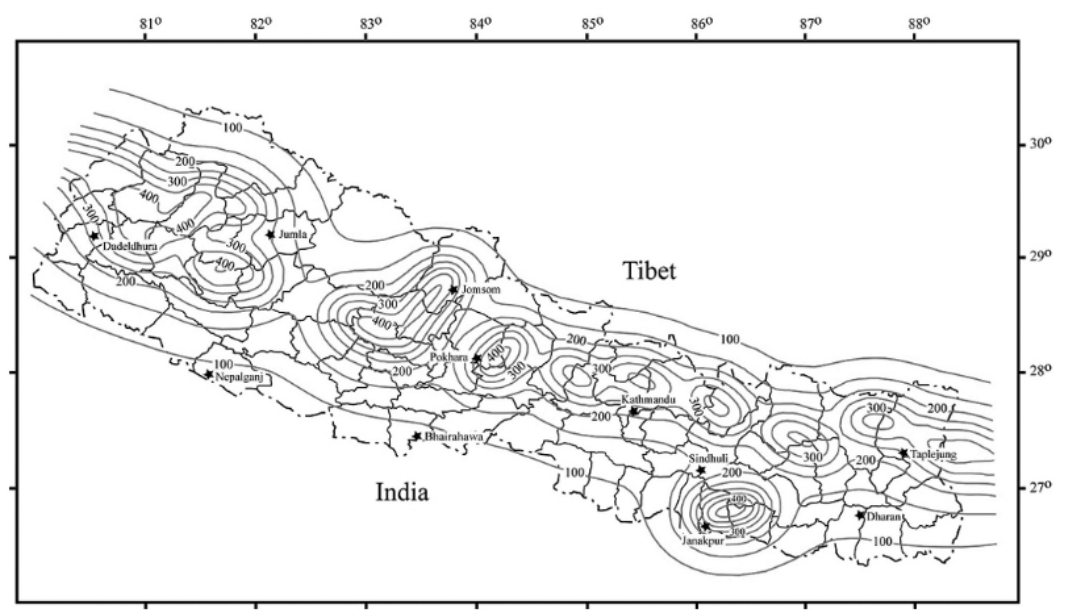

Figure 1: Seismic hazard map of Nepal [2]. Bedrock peak ground-horizontal acceleration is calculated for five hundred years to return period. Contour- interval of $100 \mathrm{gal}$

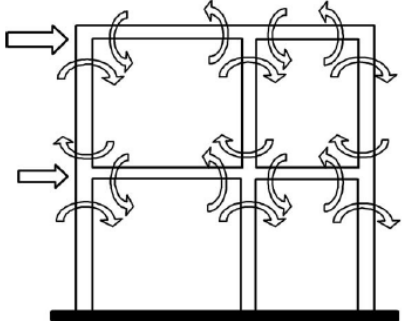

(a)

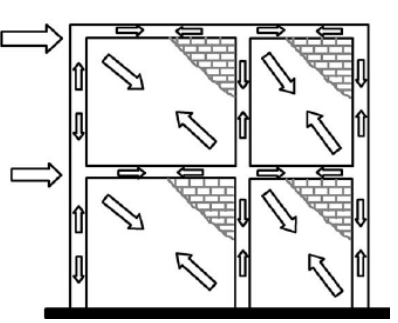

(b)

Figure 2: Change in lateral load transfer mechanism due to masonry infill (a) Predominant frame action;(b) Predominant truss action [7]

Pokhara is an important tourist city as well as the capital of the Gandaki province makes it under intense pressure of rapid urbanization. Looking at the urbanization scenario in terms of the building construction, if the constructed buildings are not well designed and detailed as per the design codes, the consequences could be more devastating and vulnerable during earthquakes. In such condition, a detailed assessment of the existing buildings in Pokhara is necessary. It gives a tentative idea about the current construction practices and responses of the structures in different level of ground shaking. 


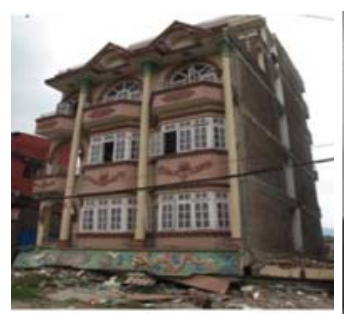

(a)

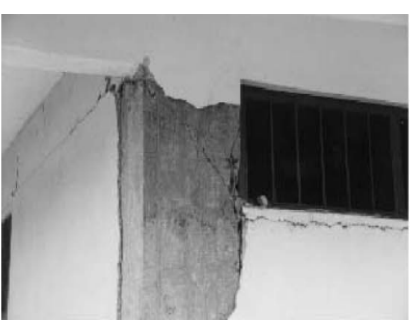

(b)

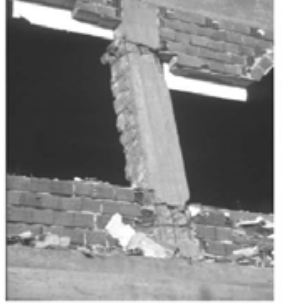

(c)

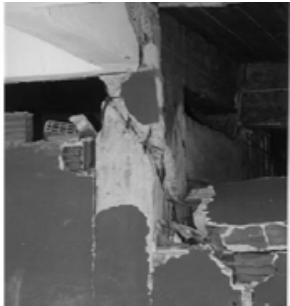

(d)

Figure 3: (a) Soft story failure; (b) Short column effect due to window opening; (c) and (d) Short column effect due to partial height of masonry infill wall [8]

Most of the current seismic design codes indirectly incorporate the nonlinear response of structure through linear elastic approach by considering the response reduction factor ' $R$ ' without comprising infill. This leads to structural response deviating radically from what is expected in the design because of the incorrect estimation of the design lateral force. The seismic loads imposed in the structures are normally higher than the loads considered during design process. Most of the earthquake design standards today include the non-linear structural response through response reduction factor. In this situation, the present study estimates the actual ' $R$ ' value for engineered design reinforced concrete buildings in Pokhara valley. The overstrength and ductility reduction factor of representative building structures are determined. For numerical analysis, non-linear pushover analysis is performed. Three representative engineered designed buildings with infilled masonry walls are selected and analysed. Finally, the structural response was examined in terms of natural period, base shear, strength, stiffness, ductility and response reduction factor.

\section{Methodology for Calculation of Response Reduction Factor:}

The response reduction factor is used in modern seismic codes to scale down the elastic response of a structure. This factor allows the designer to use linear elastic forced based design while accounting for nonlinear behavior and deformation limit. The concept of the ' $R$ ' factor is based on the fact that a well-detailed frame system could sustain the large inelastic deformation without a collapse in a severe earthquake and develop lateral strength in excess of their design strength [9].

The response reduction factor was first proposed by the ATC-19 [10]. It is described by the product of the three factors i.e. ductility factor, overstrength factor, and added viscous damping.

$$
\boldsymbol{R}=\boldsymbol{R}_{\mu} \times \boldsymbol{R}_{s} \times \boldsymbol{R}_{\zeta}
$$

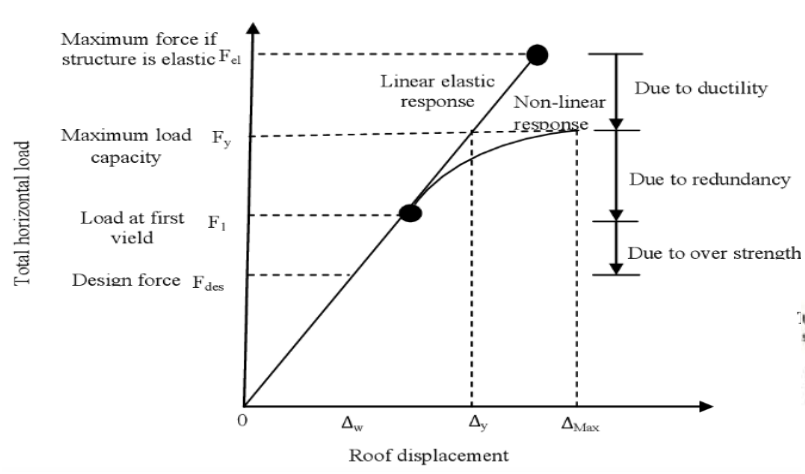

(a)

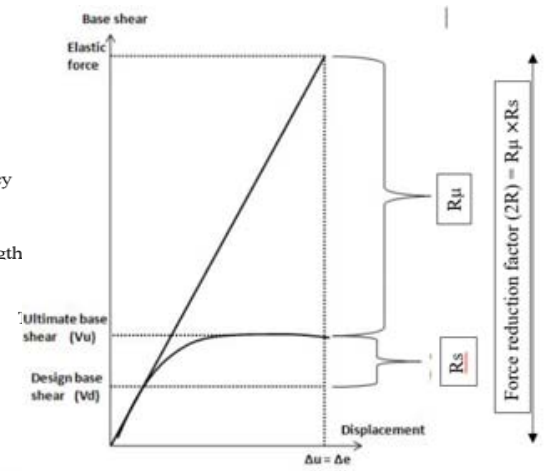

(b)

Figure 4: Base shear force vs roof lateral displacement with structure response parameter (a) Proposed 'R' by ATC-19 [10] (b) Proposed 'R' according to IS-1893 [12] 
In Eq. (1) ' $R_{\mu}$ ' is the ductility factor, ' $R_{\mathrm{s}}$ ' is the strength factor, ' $R_{\zeta}$ ' is the any added viscous damping. In the absence of any supplemental viscous damping, the ' $R_{\zeta}$ ' is taken as unity. Further ATC-34 [11] accounts for the redundancy of the structure i.e. redundancy factor, which is mostly used in the current scenario for the formulation of the response reduction factor. The evaluation of the R- factor is based on the formulation proposed by the ATC-34 [11].

$$
\boldsymbol{R}=\boldsymbol{R}_{\boldsymbol{\mu}} \times \boldsymbol{R}_{\boldsymbol{s}} \times \boldsymbol{R}_{\boldsymbol{\rho}}
$$

In Eq. (2) ' $R_{\mu}$ ' is the ductility factor, ' $R_{\mathrm{s}}$ ' is the strength factor, ' $R_{\rho}$ ' is the redundancy factor. The assessment of this factor can be obtained from the pushover curve or base shear force vs roof lateral displacement relationship (Fig. 4)

\subsection{Ductility Factor:}

Ductility factor measures the ductility of a structure as a whole. It depends on the expected response during earthquakes which is associated on the design and detailing criteria. Newmark and Hall [9] first tried to relate the ductility factor with displacement ductility ' $\mu$ ' for a single degree of freedom system. The relation of ' $R_{\mu}$ ' proposed by Newmark and hall [9] is used in the study.

$$
R_{\mu}=1.0 \text { for } T<0.2 \mathrm{sec}
$$

$$
R_{\mu}=\sqrt{2 \mu-1} \text { for } 0.2<T<0.5 \mathrm{sec}
$$

(4)

$$
R_{\mu}=\mu \text { for } T>0.5 \mathrm{sec}
$$

\subsection{Overstrength Factor:}

The researchers have specified that structure tends to have more capacity than accounted for in the analysis. The structure could take the forces considerably larger than they were designed for. This is due to the presence of reserve strength in the structure which is not accounted for in the design [13]. The primary sources of the overstrength are sequential yielding of the critical region, material overstrength, partial safety factor used for load and material, confinement of concrete, strain hardening, strength contribution of non-structural elements etc. [14]. Mathematically, it is expressed as.

$$
R_{s}=V_{1 y} / V_{d}
$$

In Eq. (8) ' $V_{1 y}$ ' is the first yielding strength and ' $V_{\mathrm{d}}$ ' is the design strength. The ATC-34 [11] use over strength and redundancy factors as two separate parameters, but some literature considered redundancy as a parameter contributing to over strength and assume both as a single unit [15]. In this study, it is assumed redundancy and over strength factor as a single unit in such condition over strength ratio becomes:

$$
R_{s}=V_{y} / V_{d}
$$

\subsection{Formulation Used in This Study:}

All the buildings were analyzed and designed with IS-1893 [12] which provides a real force for elastic structure and divides that force by $2 R$ to account for the nonlinearity of the structure. To evaluate ductility and overstrength values from the force-displacement relationship curve, bilinear idealization of the curve is needed.

$$
2 R=\frac{\text { (Elastic strength demand) }}{\text { (Design strength) }}=R_{\mu} \times R_{S}
$$

\subsection{Modelling of Frame Element and Infill Panel:}

\subsubsection{Beam and Column:}

The finite element program SAP 2000 [16] provides section designer feature to create the section of existing beam and column with reinforcement detailing but it cannot assemble all the sections having different reinforcement detailing into single unit. Since plastic hinges are formed at the most stressed section i.e. support section, we have to use support section detailing throughout the whole length of frame member.

\subsubsection{Infill Panel:}

To perform the safety assessment of existing RC infilled framed structures or to design new ones, the nonlinear behavior of these structural systems during a strong earthquake should properly be taken into account [17].

There are many different techniques proposed in the literature for the simulation of the infilled frames, which can be divided into two groups; namely micro-model and simplified macro models. The micro model considers the high level of discretization of the infill masonry panel, in which the panel is divided into numerous elements to take into account the local effect in 
detail. Whereas, the macro model is most commonly used technique due to its simplicity. In this model, infill panel is modelled as a diagonal strut with strut width and the thickness same as that of the wall. Different researchers have proposed different formulae to calculate the strut width. The method proposed by the Paulay and Priestley [5] was used in this study where the strut width is taken as one fourth of the diagonal length of masonry wall. The diagonal strut is usually connected to the intersection points of the beam and column centerlines. This strut is designed in such a manner that it only carries compression. Transfer of bending moment from $\mathrm{RC}$ frames to masonry was prevented by specifying the moment release at both ends of the strut, the moment release is accompanied by using pinned joint at the ends of the strut.

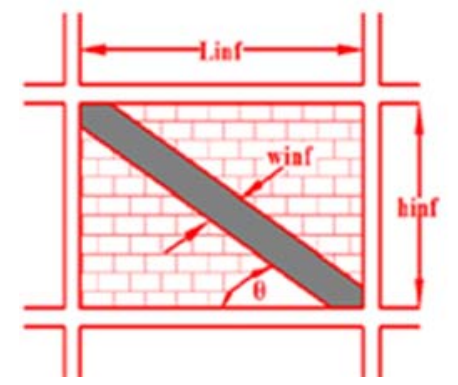

Figure 5: Typical infill modeling [18]

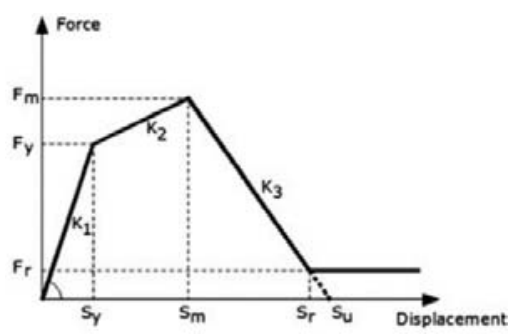

Figure 6: Force-displacement relationship for the equivalent strut model [19]

For performing nonlinear pushover analysis, user defined plastic hinges are assigned to the center of the diagonal strut which incorporate the strut behavior beyond the elastic level. For this, determination of the strength and the stiffness of the masonry beyond the elastic level is necessary. The constitutive relation proposed by Panagiotakos and Fardis [19] was used in this study to address the nonlinear behavior. The nonlinear behavior is characterized by a multilinear envelope curve.
These curves mainly have four segments. The first part shows the initial shear behavior of the un-cracked panel. The second section depends on the equivalent diagonal strut formation on the panel after the separation of the infill from the bounding frame. The third part defines the infill wall's softening behavior after the critical displacement 'Sm' and characterized by the 'K3' slope. The fourth part, horizontal line, describes the final behavior of the infill walls. The final part can also be ignored by assuming a softening line that reaches a zero residual strength 'Su' as shown in the Fig. 6.

\section{Description of the Case Study Building:}

In this study, three existing RC-MRF buildings were randomly selected and designed based on the IS-1893 [12] considering PGA value of 0.36 $\mathrm{g}$ that corresponds to zone- $\mathrm{V}$ of Indian seismic hazard map. The buildings have a maximum of 4 stories with story height $3 \mathrm{~m}$ and only the portion above the plinth level are considered during the analysis.

\subsection{Material Properties and Loading:}

The staircase dead load (DL) and live load (LL) along with wall load (with and without openingconsidering $30 \%$ ) is transferred to respective floor beam as equivalent UDL. Seismic loads are considered acting in the horizontal direction (either of the two principal directions) and not along the vertical direction. The floor diaphragms are assumed to be rigid. The unit weight of concrete and brick including plaster are assumed $25 \mathrm{kN} / \mathrm{m}^{3}$ and $20 \mathrm{kN} / \mathrm{m}^{3}$, respectively. Poisson's ratio for concrete and masonry be 0.2 , dead load on floor finish $=1.2$ $\mathrm{kN} / \mathrm{m}^{2}$, live load on floor $=2 \mathrm{kN} / \mathrm{m}^{2}(25 \%$ for earthquake), live load on roof $=1.5 \mathrm{kN} / \mathrm{m}^{2}$ (nil for earthquake, IS 1893:2002 [12], dead load in staircase $=4 \mathrm{kN} / \mathrm{m}^{2}$, live load in staircase $=3$ $\mathrm{kN} / \mathrm{m}^{2}$, full brick wall load $=12.36 \mathrm{kN} / \mathrm{m}$, half brick wall load $=6.18 \mathrm{kN} / \mathrm{m}$. All the dead loads and live loads values were taken from the IS 875 $[20,21]$ respectively. The material properties of all three buildings are identical throughout all stories. Assuming the yield strength of reinforcing steel $500 \mathrm{Mpa}$ and compressive strength of concrete $20 \mathrm{Mpa}$.

\subsection{Description of Structures:}


Himalayan Journal of Applied Science and Engineering (HiJASE), Vol. 1, Issue 1, No. 11, 2020

Due to the geometrical irregularity, the structure is analyzed with a three-dimensional (3D) model. The beam and column sections are taken as $(230 \times 430)$ and $(300 \times 300) \mathrm{mm}$, respectively. The sectional size and reinforcement detailing of the plinth beam are identical for all the three buildings $(230 \times 300) \mathrm{mm}$ and $(3-16 \phi$ top, $3-16 \phi$ bottom), the thickness of slab-100 mm, exterior and interior wall are $230 \mathrm{~mm}$ and $115 \mathrm{~mm}$ respectively. The plan and 3-D of case study building models are presented in Fig. 7. Similarly, Table 1 summarized beam-column sectional dimension and reinforcement detailing.
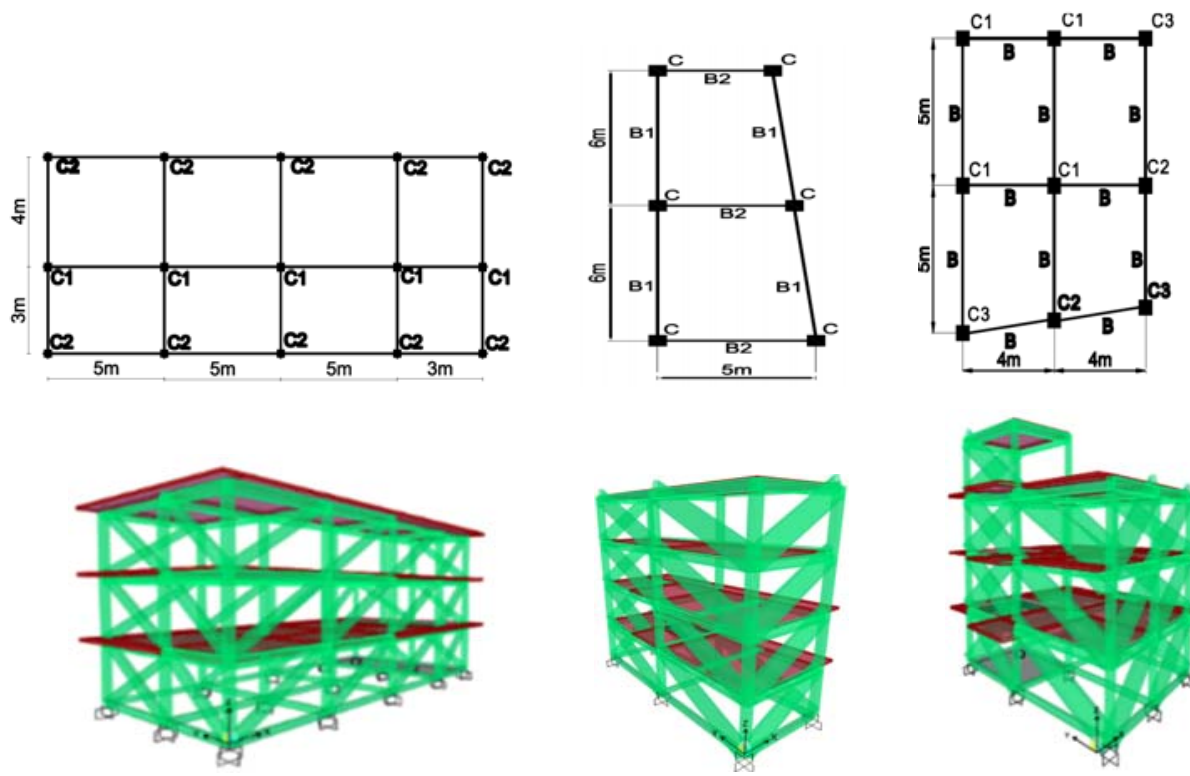

(a)

(b)

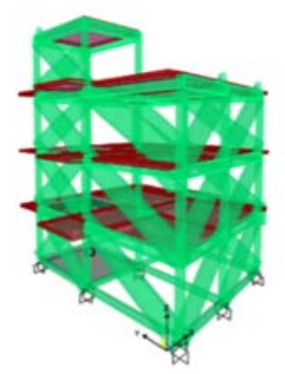

(c)

Figure 7: Plan and 3-D model of building: (a) Type 1, (b) Type 2, (c) Type 3

Table 1: Beam column dimension and reinforcement details

\begin{tabular}{|c|c|c|c|c|}
\hline $\begin{array}{l}\text { Type of } \\
\text { building }\end{array}$ & Story & Member & 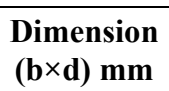 & Reinforcement details \\
\hline \multirow{6}{*}{1} & \multirow{3}{*}{$1 \mathrm{st}$} & $\mathrm{C} 1$ & $300 \times 300$ & $4-20 \phi+4-16 \phi$ \\
\hline & & $\mathrm{C} 2$ & $300 \times 300$ & $8-16 \phi$ \\
\hline & & $\mathrm{B}$ & $230 \times 430$ & $3-16 \phi$ (top), 2-16ф+1-12ф(bottom) \\
\hline & \multirow{3}{*}{$\begin{array}{l}\text { 2nd \& } \\
\text { 3rd }\end{array}$} & $\mathrm{C} 1$ & $300 \times 300$ & $8-16 \phi$ \\
\hline & & $\mathrm{C} 2$ & $300 \times 300$ & $6-16 \phi+2-12 \phi$ \\
\hline & & $\mathrm{B}$ & $230 \times 430$ & 3-16ф(top), 2-16ф+1-12ф(bottom) \\
\hline \multirow{3}{*}{2} & \multirow{3}{*}{$\begin{array}{l}\text { All floor } \\
(1,2,3 \\
\& 4)\end{array}$} & $\mathrm{C}$ & $350 \times 350$ & $6-20 \phi+2-16 \phi$ \\
\hline & & $\mathrm{B} 1$ & $230 \times 430$ & $2-16 \phi+3-12 \phi$ (top), $2-16 \phi+1-12 \phi$ (bottom) \\
\hline & & $\mathrm{B} 2$ & $230 \times 430$ & $3-16 \phi($ top $), 2-16 \phi+1-12 \phi$ (bottom) \\
\hline \multirow{9}{*}{3} & \multirow{4}{*}{$1 \mathrm{st}$} & $\mathrm{C} 1$ & $300 \times 300$ & $8-20 \phi$ \\
\hline & & $\mathrm{C} 2$ & $300 \times 300$ & $4-20 \phi+4-16 \phi$ \\
\hline & & $\mathrm{C} 3$ & $300 \times 300$ & $8-16 \phi$ \\
\hline & & $\mathrm{B}$ & $230 \times 430$ & $4-16 \phi($ top $), 2-16 \phi+1-12 \phi($ bottom) \\
\hline & \multirow{5}{*}{$\begin{array}{l}\text { 2nd \& } \\
\text { 3rd }\end{array}$} & $\mathrm{C} 1$ & $300 \times 300$ & $4-20 \phi+4-16 \phi$ \\
\hline & & $\mathrm{C} 2$ & $300 \times 300$ & $8-16 \phi$ \\
\hline & & $\mathrm{C} 3$ & $300 \times 300$ & $6-16 \phi+2-12 \phi$ \\
\hline & & $\mathrm{B}$ & $230 \times 430$ & $4-16 \phi($ top $), 2-16 \phi+1-12 \phi($ bottom $)$ \\
\hline & & $\mathrm{C} 1$ & $230 \times 430$ & $6-16 \phi+2-12 \phi$ \\
\hline
\end{tabular}




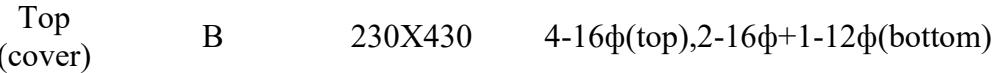

4. Analysis and Interpretation of the Result:

\subsection{Natural Period:}

The comparative result of the natural period with and without infill consideration as shown in Fig. 8 , indicates that the inclusion of the infill interaction decreases the natural period of the structure. The decrease in period ranges from 40$60 \%$ of the bare frame in both directions. The result is consistent with the previous study [22].
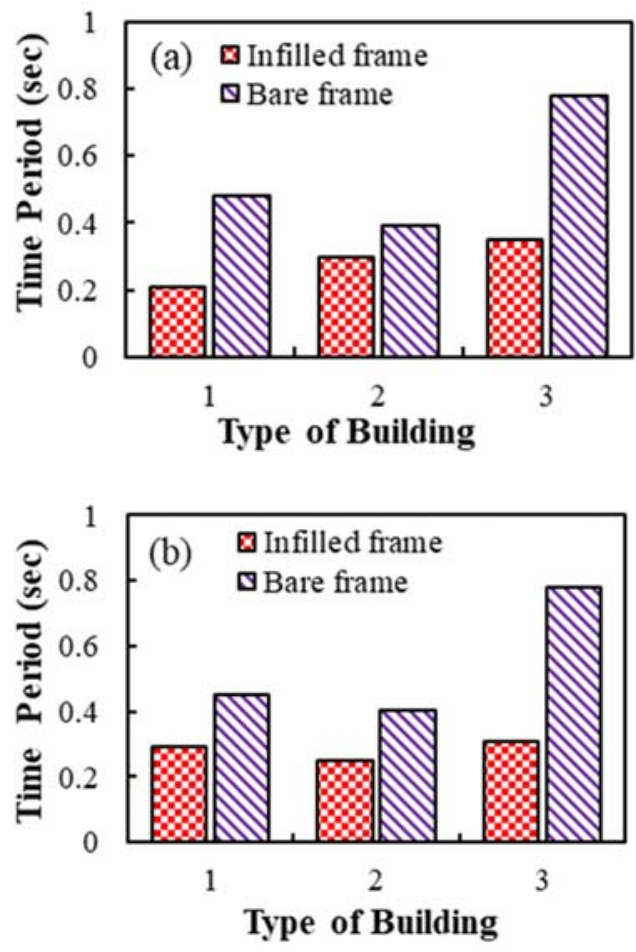

Figure 8: Comparative Eigen period with and without infilled frame in (a) X-direction and (b) Y-direction

\subsection{Base Shear Capacity:}

The seismic forces are imposed higher at the higher floor level and cantilever action accumulates these forces from top to bottom. The sum of all forces acted at the ground story are resisted in the opposite direction and termed as base shear. As indicated in the Fig. 9, the introduction of the infill drastically increases the ultimate base shear of the structure which may subsequently increase the design base shear due to decrease in the period. The increased base shear of the studied buildings with the inclusion of infilled ranged from 1.2 to 2.2 times greater than in the case of bare frame. The result is in the range to the previous study [23].
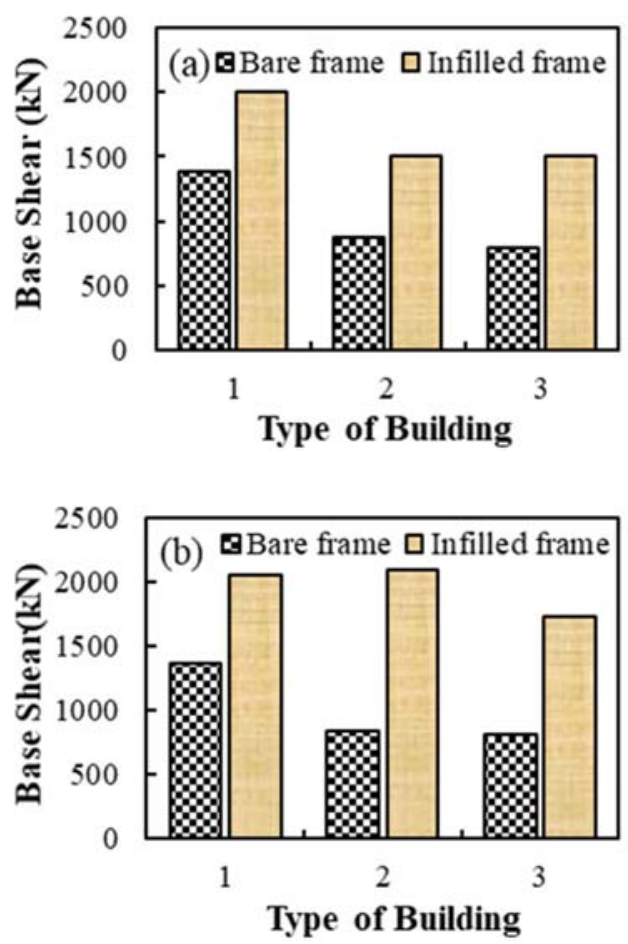

Figure 9: Comparative base shear with and without infilled frame in (a) X-direction and (b) Y-direction 

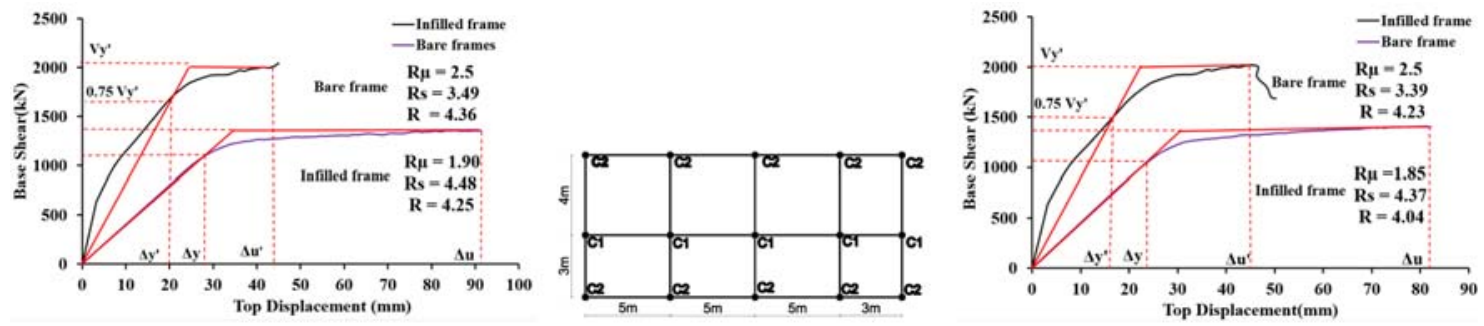

Figure 10: Type 1 capacity curve with and without considering infill in $\mathrm{X}$ and $\mathrm{Y}$-direction

\subsection{Response Reduction Factor Value:}

The presence of infill panels increases the stiffness and strength of the system. This is confirmed by studying the pushover curves for the bare frame and infill masonry structure. The study highlights that the average ' $R$ ' value of the study building models are in the range of (3.5-4). The Indian standard code [24] also mentions that inclusion of infill may increase or decrease the ' $R$ ' values which ultimately increase or decrease the design force. In such condition, code clearly specifies that the design force must be calculated with and without considering infill and use larger force out of the two conditions. Moreover, the other researchers also reported an increase in ' $R$ ' value due to substantial increased value of overstrength [25-27]. The ' $R$ ' value for studied building models are summarized in Figs 10-12.

\subsection{Comparison of Ductility Reduction Factor:}

Due to an increase in the stiffness, natural period and displacement ductility of the structure decrease. Consequently, the ductility reduction factor decreases because the ductility reduction factor is a function of natural period and displacement ductility $(\mu)$. The decreased percentage of the ductility reduction factor by the inclusion of the lateral stiffness of the infilled is about $35-45 \%$ in the both directions. Ductility reduction factor of an infilled and bare frame in both $\mathrm{X}$-direction and Y-direction in shown in Fig. 13 (a) and (b). This value is similar to the values observed in previous studies [26, 27].
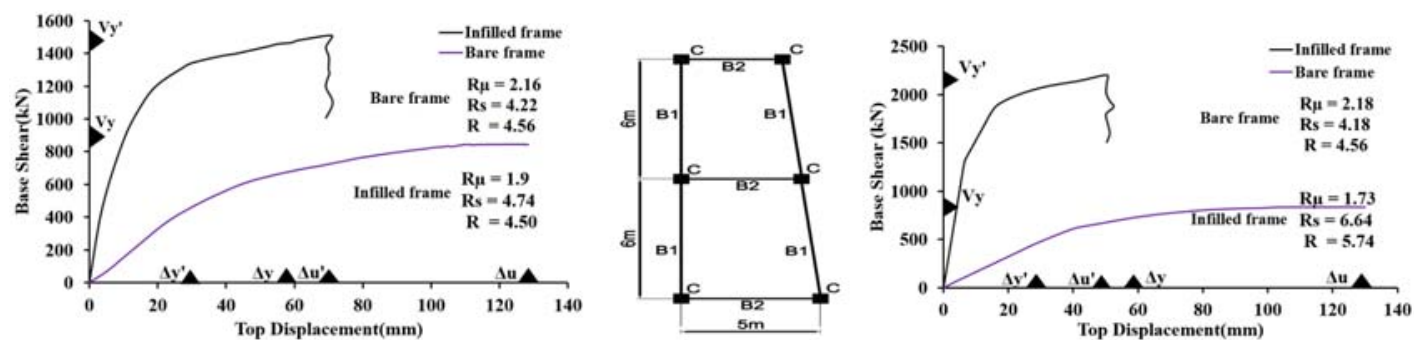

Figure 11: Type 2 capacity curve with and without considering infill in $\mathrm{X}$ and $\mathrm{Y}$-direction
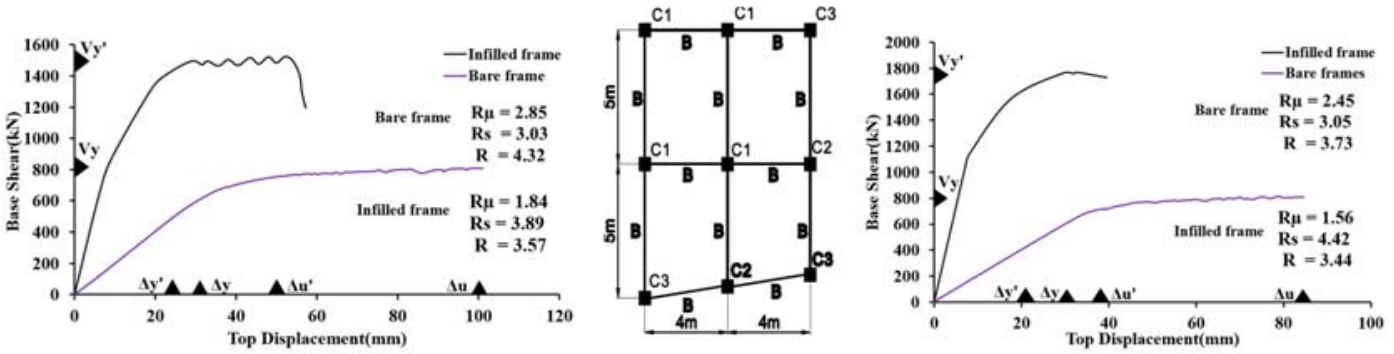

Figure 12: Type 3 capacity curve with and without considering infill in $\mathrm{X}$ and $\mathrm{Y}$-direction 

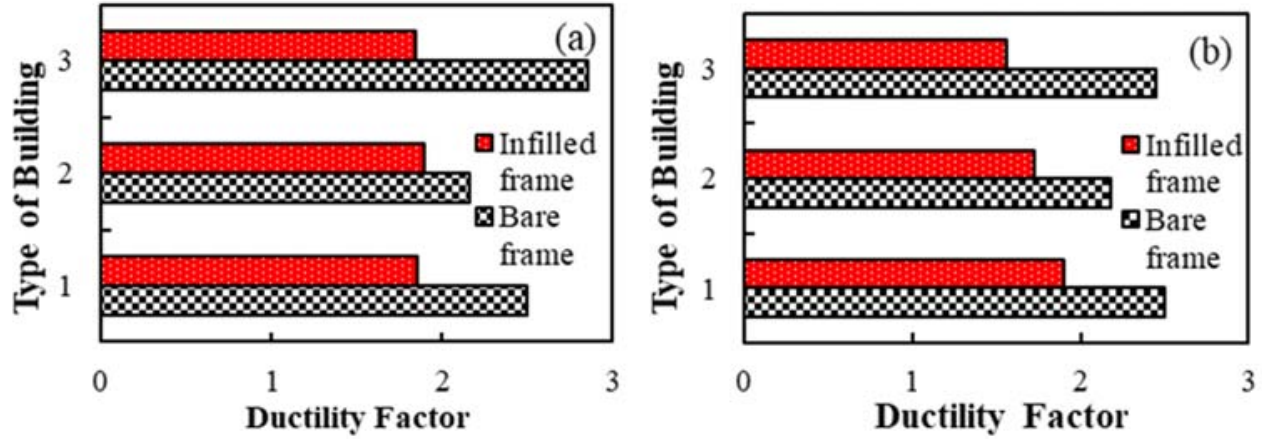

Figure 13: Ductility reduction factor of an infilled and bare frame in (a) X-direction, (b) Y-direction

\subsection{Comparison of Overstrength Factor:}

The previous study [7] concluded that the initially larger amount of lateral load attracted by the masonry infill but when it crosses its ultimate load-carrying capacity, there will be a sudden drop in the strength of the structure, the same

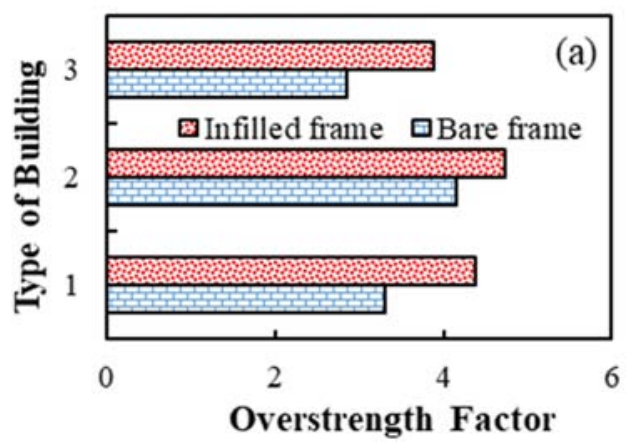

pattern is seen in the Figs. 11, $12 \&$ 13. From the above analysis, it is clear that unreinforced masonry infill frame has an average of 1.5 to 2 time's higher strength than the bare frame. Overstrength factor of an infilled and bare frame in in both X-direction and Y-direction in shown in Fig. 14.

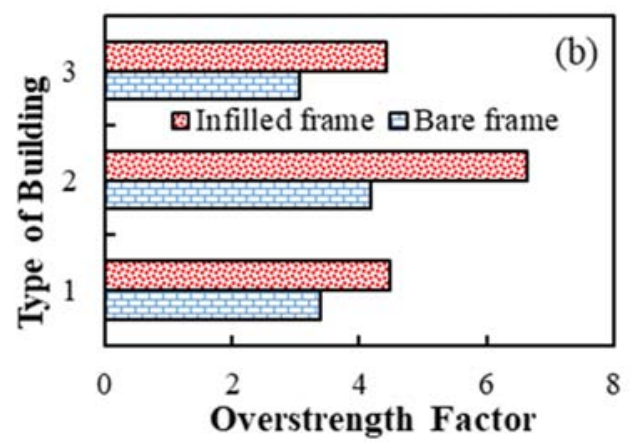

Figure 14: Overstrength factor of an infilled and bare frame in (a) X-direction (b) Y-direction

\section{Conclusions:}

The empirical expression for the determination of time period as mentioned in standard codes shows a lower value than the one calculated by the finite element approach. This shows that the code formula for estimating the time period doesn't account for the irregularities present within the building. Hence the code formula for determining the time period is insufficient to include all the responses when subjected to the earthquake excitation and should be amended. The study of mode shape shows that for regular or nearly regular building, the first and second modes are purely translational and the third mode is purely rotational. While as with the increase in the irregularity of the building the mode shapes become completely of mixed type. The study shows that with the increase in the irregularity of building, the number of modes to achieve $90 \%$ of modal mass participation for accurate determination of dynamic response increases. Under the unidirectional application of earthquake loading, the response induced in the perpendicular direction to earthquake excitation increases with increases in the plan irregularity due to lateral-torsional coupled behavior of the irregular buildin This study evaluates the response reduction factor of the existing $\mathrm{RC}$ buildings with masonry infills. In the analysis, the influence of gravity load is included but the P- $\Delta$ effect and soil-structure interaction are ignored during numerical analysis. The results clearly indicate a significant variation of fundamental time period, base shear, ductility, overstrength, and response reduction factor in the presence of infill masonry wall. Thus, considering the infill panel in the 
analysis would influence the seismic behavior of frame structure to a greater extent. Consequently, ' $R$ ' factor either decreases or increases depending upon the relative increase or decreased values of the overstrength and ductility factor. The main conclusions are summarized as:

- the presence of infills decreased the time period of structure by $40-60 \%$ compared to the bare frame.

- the inclusion of infills masonry increases the base shear from 1.2 to 2.2 times than bare frame.

- introduction of infilled decreases the displacement ductility factor by $35-45 \%$.

- for infill opening greater than $30 \%$, decreased percentage of overstrength was relatively higher than the increased percentage of displacement ductility, resulting into a decreased value of the response reduction factor.

- generally, the infill opening is considered in the range of the $30 \%$ and above for residential building.

- for the design of residential building, the study recommend the ' $R$ ' value in the range of 3.5-4.

\section{References:}

[1] D. Giardini, G. Grunthal, K. Shedlock and P. Zhang, "The GSHAP global seismic hazard map, Annali Di Deofisica," 42(6) 1999. [online]. doi: https://doi.org/10.4401/ag-3784

[2] M.R. Pandey, G.R. Chitrakara, B. Kafle, S.N. Sapkota, S. Rajaure, and U.P. Gautam, "Seismic hazard map of Nepal," National Seismological Centre, Kathmandu, Nepal 2002

[3] G. Bhattarai, "Probabilistic seismic hazard assessment and ground response," M.S. thesis, Dept. of Civil Eng., Purvanchal University, Kathmandu, Nepal 2009.

[4] M. Baranaure, A.M. Ghita and D.N. Stoica, "Influence of the infill panel masonry type on the seismic behavior of a reinforced concrete structure," Springer International Publishing Switzerland vol.14: pp.319-331, 2016.

[5] T. Pauley and M.J.N. Priestley, "Seismic design of reinforced concrete and masonry building," Wiley Interscience, New York, USA, 1992.

[6] R. J. Mainstone, "On the stiffness and strength of infilled frames," Proceeding of the Institution of Civil Engineers IV, pp. 57- 90, 1971.

[7] C. V. R. Murty and S. K Jain, "Beneficial influence of masonry infill wall on seismic performance of RCframe building," in Proc. 12WCEE: 12th World Conference on Earthquake Engineering, Auckland, New Zealand, 2000 Sunday 30 January - Friday 4 February.

[8] H. Rodrigues, H. Varum, and A. Costa, "Simplified macro- model for infill masonry panel," Journal of Earthquake Engineering, vol.14: pp.390-416, 2010.

[9] N. Newmark and W. Hall, "Earthquake spectra and design engineering monograph," Earthquake Engineering Research Institute, Berkeley 1982.

[10] Applied Technical Council [ATC], "Seismic response modification factor," ATC-19. California: Applied Technical Council; Redwood City; California 1996.

[11] Applied Technical council [ATC], "A critical review of current approaches to earthquake-resistant design," ATC-34. California: Applied Technical Council; Redwood City; California 1995.

[12] Bureau of Indian Standards [BIS], "Criteria for earthquake resistant design of structures," 5th revision, 1893 (part-1) 2002.

[13] M. Mahmoudi, "The relationship between overstrength and member ductility of RC moment-resisting frame," in Proc. Pacific Conference on Earthquake Engineering Christchurch, New Zealand 2003. 
[14] A. M. Mwafy and A. S. Elnashai, "Calibration of force reduction factor of RC building," Journal of Earthquake Engineering, vol.6 (2):pp. 239-273, 2002.

[15] S.A. Freeman, "On the correlation of code forces to earthquake demands," in Proc. 4th U.S.-Japan Workshop on the improvement of structural design and construction practices, 1990.

[16] SAP V-20, "Integrated finite element analysis and design of structure basic analysis," Reference Manual Computers and Structure Inc. Berkeley (CA, USA), 2000.

[17] M. Dolesk, and P. Fajfar, "Simplified non-linear seismic analysis of infilled reinforced concrete frames," Earthquake Engineering and Structural Dynamics, vol. 34: pp. 49-66, 2005.

[18] FEMA 356, "Pre-standard and commentary for the seismic rehabilitation of the building," Federal Emergency Management Agency (FEMA), Washington, D.C. 2000.

[19] T.B. Panagiotakos and M.N. Fardis, "Seismic response of infilled RC frames structure," in Proc. 11th World Conference on Earthquake Engineering, Acapulco 1996.

[20] Bureau of Indian Standards [BIS], "Code of practice for design loads (other than earthquake for building and structure)," 2nd revision, 875 (part-1) 1987.

[21] Bureau of Indian Standards [BIS], "Code of practice for design loads (other than earthquake for building and structure)," 2nd revision, 875 (part-2) 1987.

[22] H. Chaulagain, H. Rodrigues, E. Spacone and H. Varum, "Seismic safety assessment of existing masonry infill structure in Nepal,” Earthquake Engineering and Engineering Vibration, vol.15: pp. 251-268, 2016.

[23] H.B. Kaushik, D.C. Rai, M. Eeri and S.K. Jain, "Code approaches to seismic design of masonry infilled reinforced concrete frames," Earthquake spectra, vol. 22(4), pp. 961-983, 2006.

[24] Bureau of Indian Standards [BIS], "Criteria for earthquake resistant design of structures," 6th revision, 1893 (part-1) 2016.

[25] N. Patel and S.A. Vasanwala, "Evaluation of response reduction factor for un-reinforced masonry-infilled RC building," International Journal of Scientific and Research Publication, vol. 2, 2019.

[26] M. Shendkar and P. Kumar, "Response reduction factor of RC framed structure with semi-interlocked masonry and unreinforced masonry infills," ICI Journal, 2018. 